\title{
The Role of the Vienna Rules in the Interpretation of the ECHR
}

\author{
A Normative Basis or a Source of Inspiration?
}

\author{
Eszter Polgári*
}

\begin{abstract}
The interpretive techniques applied by the European Court of Human Rights are instrumental in filling the vaguely formulated rights-provisions with progressive content, and their use provoked widespread criticism. The article argues that despite the scarcity of explicit references to the Vienna Convention on the Law of Treaties, all the ECtHR's methods and doctrines of interpretation have basis in the VCLT, and the ECtHR has not developed a competing framework. The Vienna rules are flexible enough to accommodate the interpretive rules developed in the ECHR jurisprudence, although effectiveness and evolutive interpretation is favoured - due to the unique nature of Convention - over the more traditional means of interpretation, such as textualism. Applying the VCLT as a normative framework offers unique ways of reconceptualising some of the much-contested means of interpretation in order to increase the legitimacy of the ECtHR.
\end{abstract}

Keywords: European Convention on Human Rights, European Court of Human Rights, techniques of interpretation, the Vienna Convention on the Law of Treaties

\section{Introduction}

The European Convention on Human Rights and Fundamental Freedoms (hereinafter Convention or ECHR) was adopted in 1950 and created undoubtedly the most successful human rights regime in the world. It was drafted in a particular moment of history; the founding fathers were driven by the desire to create an effective mechanism that was capable of preventing mass human rights violations and precluding further Communist subversion on the European continent. ${ }^{1}$ The text was admittedly based on the Universal Declaration on Human Rights. The Preamble refers to the link between the two in the following terms: 'the governments of European countries ... take the first steps for the collec-

Eszter Polgári, PhD, is assistant professor at the Department of Legal Studies of the Central European University in Austria.

1. D.J. Harris, M. O'Boyle, E.P. Bates \& C.M. Buckley, Law of the European Convention on Human Rights (2018), at 3; B. Rainey, E. Wicks \& C. Ovey, Jacobs, White, and Ovey - The European Convention on Human Rights (2017), at 3-4. tive enforcement of certain of the rights stated in the Universal Declaration'. ${ }^{2}$

The Convention primarily guarantees civil and political rights and its text was far from being innovative; the geopolitical relations prevalent at the time of the drafting and the forced compromises left their mark on it. The formulation of rights reflects the drafters' strategy and motivation. Only non-controversial rights were included in the original text; the provisions embody the bare minimum states could agree on without a lengthy and heated negotiation process. The Convention textually offers rather generally worded minimal guarantees in comparison to the International Covenant on Civil and Political Rights that contains more detailed and fuller protection. The rights 'are expressed in sparse and abstract universal terms' 3 and are to be taken only as 'programmatic formulations,' ${ }^{4}$ which have been filled with content only through interpretation by the European Court of Human Rights (hereinafter ECtHR or Court). The interpretation of the text thus lies at the very heart of the European system's success and the creative solutions adopted by the ECtHR have triggered considerable amount of critique and resistance. The Court has confirmed numerous times that the ECHR is an international treaty, ${ }^{5}$ yet the question remains open whether its interpretation conforms to the international - and customary law - standards.

The article explores the possibility of the sui generis nature of the Convention being reconciled with Articles 31-33 of the Vienna Convention on the Law of Treaties (hereinafter VCLT or Vienna rules) or - as some suggest - the Court having to bend or flexibly interpret these rules in order to accommodate the interpretation techniques it resorts to. In order to provide a frame of reference, it first reviews the relevant articles of the VCLT which had been endorsed by the Court even

2. For a more detailed analysis of the relationship between the two documents see: M. Duranti, The Conservative Human Rights Revolution: European Identity, Transnational Politics, and the Origins of the European Convention (2017), at 321-4.

3. S. Greer, 'The Interpretation of the European Convention on Human Rights: Universal Principle or Margin of Appreciation?' 3 UCL Human Rights Review 1 (2010).

4. L. Wildhaber, 'The European Court of Human Rights: The Past, the Present, the Future', 22 American University International Law Review 521, at 525 (2007).

5. See for example: Rantsev v. Cyprus and Russia 25965/04 (7 January 2010), para. 273. 
before they entered into force. Although this acceptance - as discussed in part three - has not been called into question, it remains open to contestation whether the Vienna rules serve as a normative basis or merely a source of inspiration in the interpretation of the Convention. The last part examines how the Vienna rules are translated in the case-law of the ECtHR and seeks to demonstrate that all of the methods and doctrines of interpretation applied in the case-law do have basis in and may derive from the VCLT, and that the occasional slight departures are justified in light of the 'object and purpose' of the Convention. It argues that the interpretation of the ECHR is not in contradiction with or in denial of the Vienna rules, and despite the scarce explicit mentions, the jurisprudence remains committed to the interpretive framework laid down by customary international law and codified in the VCLT. When reviewing the Court's interpretive techniques, the article will not address the doctrine of the margin of appreciation; it is understood as a standard of review based on the principle of subsidiarity and as such it falls outside the scope of the VCLT. As Ulfstein correctly notes, it does not instruct how the Convention has to be interpreted - it only distributes 'the interpretational competence between the ECtHR and national organs'. ${ }^{6}$

\section{Overview of the Vienna Rules}

Interpretation is not a secondary process; '[a]ny application of a treaty ... presupposes ... a preceding conscious or subconscious interpretation of the treaty'. As the International Law Commission famously put it: 'the interpretation of documents is to some extent, an art, not an exact science'. 8 The general rules of interpretation for treaties are laid down in Articles 31-33 of the Vienna Convention on the Law of Treaties and these provisions are now considered to form part of customary international law. ${ }^{9}$ Traditional academic scholarship differentiates between three methods or approaches to the inter-

6. G. Ulfstein, 'Interpretation of the ECHR in Light of the Vienna Convention on the Law of Treaties', 24 International Journal of Human Rights 1 , at 7 (2019).

7. Schwarzenberger quoted in: O. Dörr, 'Interpretation of Treaties', in O. Dörr and K. Schmalenbach (eds.), Vienna Convention on the Law of Treaties. A Commentary (2018) 559, at 568.

8. Quoted by P. Merkouris, 'Introduction: Interpretation is a Science, is an Art, is a Science', in M. Fitzmaurice, O. Elias \& P. Merkouris (eds.), Treaty Interpretation and the Vienna Convention on the Law of Treaties: 30 Years on (2010) 1, at 8.

9. Gardiner further emphasises that in addition to being accepted as customary international law, the Vienna rules are 'not open to challenge'. R. Gardiner, 'The Vienna Convention Rules on Treaty Interpretation', in D.B. Hollis (ed.), The Oxford Guide to Treaties (2015) 475, at 476. See also: S. Sheeran, 'The Relationship of International Human Rights Law and General International Law: Hermeneutic Constraints, or Pushing the Boundaries?' in S. Sheeran and Sir N. Rodney (eds.), Routledge Handbook of International Human Rights Law (2013) 79, at 86; and Changfa Lo, Treaty Interpretation under the Vienna Convention on the Law of Treaties. A New Round of Codification (2017), at 34-47. pretation of international treaties: (1) the 'objective' method that relies primarily on the ordinary meaning of words (literal interpretation); (2) the 'subjective' approach that favours interpretation in line with the parties' intent; and (3) the 'teleological' interpretation that places emphasis on the 'object and purpose' of the treaty. ${ }^{10}$ In addition to these interpretive techniques, some take note of the systematic or contextual method that appreciates 'the meaning of terms in their nearer and wider context', ${ }^{11}$ or complement the list with the logical method that applies 'rational techniques of reasoning and ... abstract principles'. ${ }^{12}$ These are not mutually exclusive approaches, however. As Shaw submitted, 'any true interpretation of a treaty in international law [has] to take into account all aspects of the agreement, from the words employed to the intention of the parties and the aims of the particular document. ${ }^{13}$

Articles 31-33 of the VCLT follow an integrated approach and endorse aspects of all the above doctrines. The 'general rule' of treaty interpretation is set forth in Article 31(1) according to which '[a] treaty shall be interpreted in good faith in accordance with the ordinary meaning to be given to terms of the treaty in their context and in the light of its object and purpose.' The starting point of the process of interpretation is the text of the treaty, and the general rule of the VCLT requires ascertaining the ordinary meaning of its terms. ${ }^{14}$ 'Ordinary' indicates that the meaning is 'regular, normal or customary', 15 it is not based on a layman's understanding, but should rather follow the meaning 'what a person reasonably informed on the subject matter of the treaty would make of the terms used'. ${ }^{16}$ Mostly, the ordinary meaning cannot be determined in isolation; it is closely - or as Gardiner notes, 'immediately and intimately' - linked to the 'context' and the 'object and purpose' of the treaty. ${ }^{17}$

'Context' in Article 31(1) serves 'as an immediate qualifier of the ordinary meaning of the terms used in the treaty' and in this capacity it prevents 'any over-literal approach to interpretation'. ${ }^{18}$ It broadens the pool of materials that may be consulted when identifying the ordinary meaning, and adds the contextual means of interpretation which ensures internal consistency. ${ }^{19}$ Article 31(2)-(3) details the sources or categories of evidence that may be used - 'in addition to the text, including its preamble and annexes' - to establish the 'context' referred to in the 'general rule': respect is paid

10. See for example: S. Dothan, 'The Three Traditional Approaches to Treaty Interpretation: A Current Application to the European Court of Human Rights', 42 Fordham International Law Journal 765, at 766 (2019); or M.N. Shaw, International Law (2008), at 932.

11. R.M.M. Wallace, International Law (2002), at 239-40.

12. M.E. Villiger, Commentary on the 1969 Vienna Convention on the Law of Treaties (2009), at 422.

13. M.N. Shaw, International Law (2003), at 839.

14. Villiger, above n. 12, at 426.

15. R. Gardiner, Treaty Interpretation (2015), at 183-4.

16. Dörr, above n. 7, at 581 .

17. Gardiner, above n. 15, at 181.

18. Ibid., at 197.

19. Villiger, above n. 12, at 427 . 
to both 'historical context' and 'forward-looking context'. ${ }^{20}$ Paragraph (2) refers to those agreements and instruments that were drawn up between the parties in connection with the conclusion of the particular treaty, while paragraph (3) adds subsequent agreements and practice, and any relevant rules of international law ${ }^{21}$ to the laundry list that have to be taken into consideration together with 'context'. 22

Reference to the 'object and purpose' in Article 31(1) injects the teleological approach into treaty interpretation. Textually, together with 'context', these are 'modifiers to the ordinary meaning of a term which is being interpreted in the sense that the ordinary meaning is to be identified in their light'. ${ }^{23}$ The concept of the 'object and purpose' is elusive. Buffard and Zemanek attempted to distinguish and define the two concepts in the following way:

[t]he object of a treaty is the instrument for the achievement of the treaty's purpose, and this purpose is, in turn, the general result which the parties want to achieve by the treaty. While the object can be found in the provisions of the treaty, the purpose may not always be explicit and be prone to a more subjective understanding. ${ }^{24}$

The fact that the singular form is used in the general rule suggests that it was intended to refer to 'a single overarching notion of the telos of the treaty as a whole'. ${ }^{25}$ The VCLT does not specify where the 'object and purpose' may be found; traditionally, the title of the treaty, its preamble and some general clauses serve as sources. ${ }^{26}$ Others also suggest that to establish the 'object and purpose', the full text of the treaty has to be consulted, and generally some intuition and common sense may also be helpful. ${ }^{27} \mathrm{~A}$ treaty may have multiple 'objects and purposes'. ${ }^{28}$ It is, however, important to note that all the mentions of the 'object and purpose' in the VCLT link it to the treaty itself either explicitly or through the use of a possessive pronoun. Hence, textually, the text does

20. B. Çali, 'Specialized Rules of Treaty Interpretation: Human Rights', in D.B. Hollis (ed.), The Oxford Guide to Treaties (2012) 525, at 527.

21. Article 31 (3) (c) is often labelled as a tool for systemic interpretation or as the reflection of 'the principle of systemic integration'. See for example: C. McLachlan, 'The Principle of Systemic Interpretation and Article 31(3) (c) of the Vienna Convention', 54 International and Comparative Law Quarterly 279, at 280 (2005); or U. Linderfalk, 'Who Are "the Parties"? Article 31 Paragraph 3(c) of the 1969 Vienna Convention, and the "Principle of Systemic Integration" Revisited', 55 Netherlands International Law Review 343 (2008).

22. VCLT Article 31(3): 'There shall be taken into account, together with the context: (a) any subsequent agreement between the parties regarding the interpretation of the treaty or the application of its provisions; (b) any subsequent practice in the application of the treaty which establishes the agreement of the parties regarding its interpretation; (c) any relevant rules of international law applicable in the relations between the parties.'

23. Gardiner, above n. 15, at 211.

24. Quoted ibid., at 213.

25. Dörr, above n. 7, at 585

26. For example: Villiger, above n. 12 , at 428

27. Dörr, above n. 7, at 585-6.

28. Villiger, above n. 12 , at 427 not support taking the 'object and purpose' of a particular provision into account for interpretation. ${ }^{29}$

Finally, Article 31(1) of the VCLT grants a prime place to good faith. It is a subjective requirement addressed to the interpreter, and the concept is understood to operate on the presumption that the terms of the treaty are 'intended to mean something, rather than nothing'. ${ }^{30} \mathrm{It}$ relates to the prohibition to abuse rights or evade obligations, and it applies to the entire process of interpretation. ${ }^{31}$ Some link good faith to the principle of effectiveness. Dörr, for instance, emphasises that the latter is ' $\mathrm{a}$ special application of the object and purpose test and the good faith rule and, therefore, an integral part of the general rule of interpretation laid down in Art 31',32

Historical interpretation and recourse to the travaux préparatoires remained only supplementary means of interpretation as pronounced in Article 32. ${ }^{33}$ Finally, Article 33 clarifies the interpretation of treaties authenticated in two or more languages; the provision - as a starting point - treats each version equally authoritative, unless the treaty itself indicates otherwise or the parties agreed on which text should prevail. The presumption is that terms have the same meaning in each authentic text. However, this presumption is rebuttable; the parties can make arrangements for potential discrepancies and prescribe which version should have precedence as indicated in paragraph 1 , or if they have not done so, then paragraph 4 offers a solution. ${ }^{34}$ Consequently, in case 'a comparison of the authentic texts discloses a difference of meaning which the application of articles 31 and 32 does not remove, the meaning which best reconciles the texts, having regard to the object and purpose of the treaty, shall be adopted'. ${ }^{35}$

The 'general rule' detailed in Article 31 follows the 'crucible' approach: '[a]ll the various elements, so far as they are present in any given case, would be thrown into the crucible and their interaction would give the legally relevant interpretation'. ${ }^{36}$ In sum, Article 31(1) combines

29. See also: J. Klabbers, 'Some Problems Regarding the Object and Purpose of Treaties', in S. Davidson (ed.), The Law of Treaties (2004) 167, at 180. Gardiner, however, notes that there are tribunals that invoke the 'object and purpose' of a particular provision. See Gardiner, above n. 15 , at $220-1$

30. Villiger, above n. 12 , at 425

31. The principle of pacta sunt servanda is entrenched also in Article 26 of the VCLT.

32. Dörr, above n. 7, at 579. See also Gardiner, above n. 15, at 168.

33. Article 32 prescribes the following: 'Recourse may be had to supplementary means of interpretation, including the preparatory work of the treaty and the circumstances of its conclusion, in order to confirm the meaning resulting from the application of Article 31, or to determine the meaning when the interpretation according to Article 31: (a) Leaves the meaning ambiguous or obscure; or (b) Leads to a result which is manifestly absurd or unreasonable.' See also: A. Cassese, International Law (2005), at 179.

34. For a more detailed analysis see Villiger, above n. 12, at 454-62

35. VCLT Article 33(4). The ECtHR in James and Others explicitly referred to Article 33 when interpreting 'in the public interest' in Article 1 of Protocol no. 1, and it opted for 'an interpretation that best reconciles the language of the English and French texts having regard to the object and purpose of Article 1 (P1-1)'. James and Others v. the United Kingdom 8793/79 (21 February 1986), A98, para. 42.

36. Yearbook of the International Law Commission (1966) vol. II, 95. The use of the singular rule was an intentional choice among the drafters, 
three principles (interpretation in good faith, according to the ordinary meaning, which is determined in light of its 'context' and 'object and purpose'). ${ }^{37}$ One may argue that seemingly it gives priority to textual interpretation, and the 'context' and the 'object and purpose' of the treaty may be perceived as subordinated or secondary to that. However, there is consensus among scholars that no interpretive technique is superior to the others - they are of equal value and the formulation of the general rule is merely the reflection of 'a logical progression'. ${ }^{38}$

\section{The VCLT's Reception in the Case-law of the ECtHR - General Overview}

To date, only a small portion of the judgments delivered by the ECtHR mentions explicitly the Vienna rules. ${ }^{39}$ However, the present article argues that the scarcity of references does not indicate - as Letsas has submitted 'that the VCLT has played very little role in the ECHR case law'. ${ }^{40}$ On the contrary, it seeks to demonstrate that the interpretive techniques and methods applied by the Court have basis in the 'general rule' set out in the VCLT. ${ }^{41}$

The ECtHR endorsed in Golder v. the United Kingdom as 'in essence generally accepted principles of international law' - Articles 31-33 already, in 1975, five years before the VCLT entered into force. ${ }^{42}$ In the case, the Court discussed at length the relevance and applicability of the VCLT and, arguably, settled the interpretive rules that have been applied in the jurisprudence ever

and this supports the 'crucible' approach. See: Gardiner, above n. 9, at 480.

37. Dörr, above n. 7, at 580

38. M.D. Evans, International Law (2003), at 186

39. As of 22 April 2021 eighty-one Grand Chamber judgments or decisions mentioned or discussed the VCLT. References to the VCLT are barely more frequent in Chamber judgments and decisions (in total eightyeight). The Plenary Court invoked the rules of the VCLT ten times. In addition to Articles 31-33, it needs to be noted, however, that the Court or the authors of the separate opinions did not exclusively refer to Articles 31-33 (rules on interpretation): Article 26 ('Pacta sunt servanda'), Article 27 ('Internal law and observance of treaties'), and Article 28 ('Non-retroactivity of treaties') were all mentioned several times. The present analysis relies predominantly on judgments and decisions delivered by the Grand Chamber as those offer the most comprehensive and detailed discussions on the role of the Vienna rules.

40. G. Letsas, 'Strasbourg's Interpretive Ethic: Lessons for the International Lawyer', 21 European Journal of International Law 509, at 512 (2010).

41. Villiger accords less importance to the sheer number of explicit mentions and draws attention to the fact that the references are "persistently present" in the case-law. M.E. Villiger, "Articles 31 and 32 of the Vienna Convention on the Law of Treaties in the Case-Law of the European Court of Human Rights', in J. Bröhmer, R. Bieber, C. Callies, et. al. (Herausgeber), Internationale Gemeinschaft und Menschenrechte: Festschrift für Georg Ress (2005) 317, at 330. See also: J. Gerards, General Principles of the European Convention on Human Rights (2019), at 47-51.

42. Golder v. the United Kingdom 4451/70 (21 February 1975), A18, para. 29. since. ${ }^{43}$ The judgment embraced the 'crucible approach' and emphasised that '[i]n the way in which it is presented in the "general rule« in Article 31 of the Vienna Convention, the process of interpretation of a treaty is a unity, a single combined operation; this rule, closely integrated, places on the same footing the various elements enumerated in the four paragraphs of the Article. ${ }^{44}$ In the given case, the Court established that Article 6(1) contains the right of access to court 'based on the very terms of the first sentence of Article 6(1) .. read in its context and having regard to the object and purpose of the Convention, a lawmaking treaty ..., and to general principles of law' without resorting to the supplementary means of interpretation set out in the VCLT. ${ }^{45}$

The Court in Golder accepted the VCLT as a guiding framework and as starting point for interpretation, and has reaffirmed this position numerous times. ${ }^{46}$ Several judgments asserted that following the VCLT rules on interpretation is imperative; 'as an international treaty, the Convention must be interpreted in the light of the rules of interpretation provided for in Articles 31-33 of [the VCLT]'; ${ }^{47}$ while at times the Court appeared to have voiced a more cautious approach indicating that the VCLT is relevant, yet not the only source of guidance. In Demir and Baykara v. Turkey, for instance, the Court emphasised that '[i]n order to determine the meaning of the terms and phrases used in the Convention, the Court is guided mainly by the rules of interpretation provided for in Articles 31-33 of [the VCLT]' ${ }^{48}$ It also occurs that the Court merely recalls the relevant provisions of the VCLT under the heading of 'International law and practice', 49 'Relevant international law materials ${ }^{50}$ or 'Relevant domestic law and practice and international texts', 51 while other judgments contain a more focused summary of the applicable principles tail-

43. G. Letsas, 'Intentionalism and the Interpretation of the ECHR', in M. Fitzmaurice, O. Elias \& P. Merkouris (eds.), Treaty Interpretation and the Vienna Convention on the Law of Treaties: 30 Years on (2010) 257, at 259.

44. Golder, above n. 42 , para. 30

45. Ibid., para. 36.

46. Hassan v. the United Kingdom [GC] 29750/09 (16 September 2014), ECHR 2014-VI 1, para. 100.

47. See for example: Magyar Helsinki Bizottság v. Hungary [GC] 18030/11 (8 November 2016), para. 118.; Mihalache v. Romania [GC] 54012/10 (8 July 2019), para. 90; or Rantsev, above n. 5, para. 273.

48. Demir and Baykara v. Turkey [GC] 34503/97 (12 November 2008), ECHR 2008-V 395, para. 65 (emphasis added). The same formulation appears in Saadi v. the United Kingdom [GC] 13229/03 (29 January 2008), ECHR 2008-I 31, para. 61. In Hirsii Jamaa and Others v. Italy the Grand Chamber noted that the Court "draws on" the provisions of the VCLT, however, the subsequent discussion on the relevance of the Vienna rules dispels the doubts about their role and does not signal a firm deviation from the Court's commitment. Hirsii Jamaa and Others v. Italy [GC] 27765/09 (23 February 2012), ECHR 2012-II 97, para. 170 (emphasis added). See also Ulfstein, above n. 6, at 2-3.

49. E.g. Molla Sali v. Greece [GC] 20452/14 (19 December 2018), para. 63.

50. E.g. Al-Jedda v. the United Kingdom [GC] 27021/08 (7 July 2011), ECHR 2011-IV 305, para. 47.

51. E.g. Sabri Güneş v. Turkey (Preliminary objection) [GC] 27396/06 (29 June 2012), para. 20. 
ored to the interpretive needs of the Court in the case at hand. ${ }^{52}$

Although it recognised the authority of the VCLT, the Court has also consistently emphasised that the Convention is unique and it has a 'special character as a treaty for the collective enforcement of human rights and fundamental freedoms', ${ }^{53}$ which may prevent the mechanical application of the Vienna rules. The enforcement is ensured by the ECtHR, ${ }^{54}$ and it is entrusted with the power to authoritatively interpret the Convention. ${ }^{55}$ The Court eloquently explained the peculiarities of the Convention in Ireland v. the United Kingdom:

Unlike international treaties of the classic kind, the Convention comprises more than mere reciprocal engagement between contracting States. It creates, over and above a network of mutual, bilateral undertakings, objective obligations which, in the words of the Preamble, benefit from a 'collective enforcement'. 56

For this reason, unlike in general international law, one must give preference to the interpretation 'that is most appropriate in order to realise the aim and achieve the object of the treaty, not that which would restrict to the greatest possible degree the obligations undertaken by the Parties. ${ }^{57}$

The aims of the European human rights regime are laid down in general terms in the Preamble to the Convention: first, when the Council of Europe's aim is recalled, i.e. 'the achievement of greater unity between its members', and the method which contributes to its achievement is 'the maintenance and further realisation of Human Rights and Fundamental Freedoms'. Second, the commitment of the signatory governments 'to take the first steps for the collective enforcement of certain of the rights stated in the Universal Declaration' more specifically relates to the content of the Convention and may be understood as a broad formulation of its 'object and purpose'. In one of its early judgments, the Court pronounced that 'the main purpose [of the Convention] is to lay down certain international standards to be observed by the Contracting States in their relations

52. E.g. Correia de Matos v. Portugal [GC] 56402/12 (4 April 2018), para. 134, where the Court invoked Article 31 (3) (c) of the VCLT and emphasised the need for systemic integration when interpreting Article 6 of the Convention. The same provision is referenced in - among others - Neulinger and Shuruk v. Switzerland [GC] 41615/07 (6 July 2010), ECHR 2010-V 193, para. 131

53. Soering v. the United Kingdom 14038/88 (7 July 1989), A161, para. 87.

54. ECHR, Article 19

55. ECHR, Article 32.

56. Ireland v. the United Kingdom 5310/71 (18 January 1978), A25, para. 239. See also: Austria v. Italy 788/60 (11 January 1961), 4 Yearbook 116,138 .

57. Wemhoff v. Germany 2122/64 (27 June 1968), A7, 'As to the Law', para. 8. See also: F. Matscher, 'Methods of Interpretation of the Convention', in R. St. J. Macdonald, F. Matscher \& Herbert Petzold (eds.), The European System for the Protection of Human Rights (1993) 63, at 66. with persons under their jurisdiction', 58 and subsequent case-law has further clarified this understanding:

the object and purpose of the Convention as an instrument for the protection of individual human beings require that its provisions be interpreted and applied so as to make its safeguards practical and effective ... In addition, any interpretation of the rights and freedoms guaranteed has to be consistent with 'the general spirit of the Convention, an instrument designed to maintain and promote the ideals and values of a democratic society'. 59

The 'special character' of the Convention can thus be summed up as the following: in the interpretation of the $\mathrm{ECHR}$, the restrictive approach to state obligations is abandoned in favour of understanding duties objectively, and in accordance with its 'object and purpose' effective interpretation is to be applied. Furthermore, the Court perceives the Convention 'as a constitutional instrument of European public order (ordre public) ${ }^{\prime 60}$ adding a constitutionalist vision to its role in the European legal space. ${ }^{61}$

The unequivocal and recurring acknowledgement of the Convention's 'special character' and the constitutionalisation of the ECtHR, it is argued, does not - and has not - weakened the Court's commitment to the VCLT, ${ }^{62}$ and the Vienna rules do not constitute a 'stumbling block' in creating unique interpretive approaches, as was suggested by some. ${ }^{63}$ The following sections will illustrate that the interpretive techniques applied by the Court do not bend the interpretive rules of the VCLT, and the Court has not developed a competing framework for interpretation. The VCLT is deemed to be - as Çali observed - 'flexible enough to incorporate human rights treaties', such as the Convention. ${ }^{64}$ Yet, the full endorsement is coupled with reservations or adjustments: the 'special character' of the Convention prompted occasional departure from traditional public international law, as is shown later. ${ }^{65}$

58. Case 'Relating to Certain Aspects of the Laws on the Use of Languages in Education in Belgium' v. Belgium (Preliminary Objection) 1474/62; $1677 / 62 ; 1691 / 62 ; 1769 / 63 ; 1994 / 63 ; 2126 / 64$ (9 February 1967), A5, 19

59. Soering, above n. 53 , para. 87

60. Loizidou v. Turkey (Preliminary Objections) [GC] 5318/89 (23 March 1995), A310, para. 75. See also: A. Orakhelashvili, ‘European Convention on Human Rights and International Public Order', 5 Cambridge Yearbook of European Legal Studies 237 (2002-2003).

61. See: C. Grabenwarter, 'The European Convention on Human Rights: Inherent Constitutional Tendencies and the Role of the European Court of Human Rights', ELTE Law Journal 101, 103 (2014).

62. See more recently: N.D. and N.T. v. Spain [GC] 8675/15; 8697/15 (13 February 2020), para. 172; or Naït-Litman v. Switzerland [GC] 51357/07 (15 March 2018), para. 174

63. This reservation was voiced by M. Forowicz, The Reception of International Law in the European Court of Human Rights (2010), at 69.

64. Çali, above n. 20, at 526.

65. L. Wildhaber, 'The European Convention on Human Rights and International Law', 56 International and Comparative Law Quarterly 217, at 220 (2007). 


\section{The ECtHR's Interpretive Techniques in Light of the Vienna Rules}

\subsection{Textual Interpretation: Reliance on the Ordinary Meaning}

According to Article 31(1) of the VCLT, establishing the ordinary meaning of terms is the 'starting point' of the interpretive process and it is not any different for the ECtHR either. ${ }^{66}$ The Court has explicitly relied on the ordinary meaning of terms in order to interpret provisions of the Convention. However, oftentimes the results of grammatical interpretation are considered rather evident and judgments do not devote lengthy parts to describing the Court's inquiry. ${ }^{67}$ For instance, in Luedicke, Belkacem and Koģ v. Germany, ${ }^{68}$ the Court had to decide whether the right 'to have the free assistance of an interpreter' guaranteed in Article 6(3) e) allows a domestic court to impose an obligation to bear the costs of interpretation. The Court carefully examined both the English and French version of the text and with the help of dictionaries defined the terms 'gratuitement / free'. As the words in both languages have a 'clear and determinate meaning' and they denote 'a once and for all exemption or exoneration', a conditional or temporary remission is not sufficient. ${ }^{69}$ This interpretation is supported - or at least not defeated - by the 'object and purpose' of Article 6 and the 'context' of the provision at issue..$^{70}$

A different approach was followed in Fohnston and Others v. Ireland, where the Court was called upon to rule - among others - on the compatibility of the Irish divorce ban with Article 12. ${ }^{71}$ In order to answer the question of whether the right to marry encompasses the right to divorce, the Court turned to examining 'the ordinary meaning to be given to terms [of Art. 12] in their context and in the light of its object and purpose'. ${ }^{72}$ The meaning of the 'right to marry' was 'clear': it applies to 'the formation of marital relationships but not to their dissolution' ${ }^{73}$ This conclusion was further confirmed by the provision's 'object and purpose' as evidenced by the travaux préparatoires. The drafters intentionally omitted reference to divorce from Article 12 and they consciously deviated from the wording of Article 16 of the Universal Declaration of Human Rights, and this may not be 'corrected' by evolutive interpretation responding to social developments. States also had an opportunity to include the right to divorce

66. Magyar Helsinki Bizottság, above n. 47, para. 119

67. See also: J.G. Merrills, The Development of International Law by the European Court of Human Rights (1993), at 70.

68. Luedicke, Belkacem and Koç v. Germany 6210/73; 6877/75; 7132/75 (28 November 1978), A29.

69. Ibid., para. 40.

70. Ibid., para. 46

71. Johnston and Others v. Ireland 9697/82 (18 December 1986), A112.

72. Ibid., para. 51.

73. Ibid., para. 52. when Article 5 of Protocol no. 7 adding further rights to spouses was drafted. ${ }^{74}$

It is important, however, to recall what the Court held about the role of the preparatory works in the Magyar Helsinki Bizottság v. Hungary case thirty years later: they 'are not delimiting for the question whether a right may be considered to fall within the scope of an Article of the Convention if the existence of such a right was supported by the growing measure of common ground that had emerged in the given area'. ${ }^{75}$ Intentionalism was thus subordinated to evolutive interpretation discussed later. The Court - as Letsas observes - not only read into the Convention rights that the drafters did not explicitly intend to provide, but also rights that the drafters openly did not intend to grant. ${ }^{76}$ The fact that the case-law detached the ordinary meaning from the intention of the drafters runs counter to the prevalent approach in general international law that advocates for the relativity of the terms of a treaty, arguing that a meaning reflecting the common intention of the parties is to be preferred. ${ }^{77}$ For the ECtHR, the textual argument is rarely decisive; it is the starting point, but the Court links it to the other elements listed in Article 31(1) of the VCLT, i.e. the 'context' and the 'object and purpose' of the provision or the ECHR as a whole. ${ }^{78}$

\section{2 'Context'}

The VCLT regards both the intrinsic and the extrinsic sources of 'context' listed in Article 31(2) instrumental for establishing the ordinary meaning. The intrinsic sources of 'context' primarily encompass the text of the treaty (i.e. the other provisions), its preamble and the annexes, or in case of the ECHR, the protocols. ${ }^{79}$ Furthermore, the Vienna rules mandate recourse to two extrinsic sources that are to be included in the 'context': '(a) any agreement relating to the treaty which was made between all the parties in connexion with the conclusion of the treaty' and '(b) any instrument which was made by one or more parties in connexion with the conclusion of the treaty and accepted by the other parties as an instrument related to the treaty'. As Dörr explains, these sources have to meet some conditions: they need to backed by a general consensus of all the parties (i.e. those who are bound by the given treaty), they need to 'relate to the substance of the treaty', and their accept-

74. Ibid., para. 53. For further examples see e.g. Rainey, Wicks \& Ovey, above n. 1, 68-9.

75. Magyar Helsinki Bizottság, above n. 47, para. 137

76. Letsas, above n. 40, 518. For the latter see e.g.: Young, James and Webster v. the United Kingdom 7601/76; 7806/77 (13 August 1981), A44, paras. 51-2; or Sigurdur A. Siguriónsson v. Iceland 16130/90 (30 June 1993), A264, para. 35.

77. See for example: A. Aust, Handbook of International Law (2012), at 9 or Dörr, above n. 7, at 580 .

78. For example: Loizidou, above n. 60, para. 86. See also: F. Ost, 'The Original Canons of Interpretation of the European Court of Human Rights', in M. Delmas-Marty (ed.), The European Convention for the Protection of Human Rights: International Protection versus National Restrictions (1992) 283, at 288-9; or J. Gerards, 'The European Court of Human Rights', in A. Jakab, A. Dyevre \& G. Itzcovich (eds.), Comparative Constitutional Reasoning (2017) 237, at 263.

79. VCLT Article 31(2) 
ance has to fall 'in a certain temporal proximity to the process of conclusion'. ${ }^{80}$ These external sources do not seem to play a significant - or any - role in the interpretation of the ECHR; to date the ECtHR has not invoked them in any of its judgments, while it frequently refers, for example, to the Preamble to the Convention. ${ }^{81}$

The ECtHR has consistently showed respect to the internal 'context' of the ECHR, which is best illustrated by the references to the need to avoid contradictory or inconsistent interpretation of its provisions. This stance is profoundly summarised by the Grand Chamber judgment in Saadi v. the United Kingdom:

[t]he Court must have regard to the fact that the context of the provision is a treaty for the effective protection of individual human rights and that the Convention must be read as a whole, and interpreted in such a way as to promote internal consistency and harmony between its various provisions. ${ }^{82}$

Internal 'context' has been considered in the case-law in various ways, not necessarily in the most coherent manner, and the need to promote internal harmony between different provisions of the Convention has not prevented the Court from dismissing the government's objection arguing that the matter falls within the scope of a detailed provision in a protocol to which the respondent state is not party. The Court thus accepted in support of the applicant's claim that Article 8 - for example applies to paternity issues in spite of the clear wording of Article 5 of Protocol no. $7{ }^{83}$ This attitude - although not fully in line with international law - reflects the uniqueness of the ECHR and the understanding that the protection of individual rights may trump the restrictive interpretation of state obligations. Yet, without dismissing the special nature of the Convention, it may be argued that such interpretation may render the adoption of protocols meaningless. As in his concurring opinion Judge Gersing in the above mentioned Rasmussen v. Denmark case observed the following: The mere fact that a separate protocol had been drawn up to guarantee equality between spouses 'in their relations with their children' indicates that Article 8 was not understood to protect these aspects of private and family life. ${ }^{84}$

Reference to the internal 'context' of a provision, however, does not always lead to the results the applicants have hoped for. In Fohnston and Others v. Ireland, the intentional omission of any reference to divorce from the text of Article 12 barred the Court from deriving it 'with consistency' - from Article 8, despite the unquestionable social developments. ${ }^{85}$ The drafters' intent reflected in the text also hindered - at least initially -

80. Dörr, above n. 7, at 590 .

81. In addition to Golder, above n. 42, see: Rotaru v. Romania [GC] 28341/95 (4 May 2000), ECHR 2000-V 109, para. 59.; or Simeonovi v. Bulgaria [GC] 21980/04 (12 May 2017), para. 131.

82. Saadi, above n. 48 , para. 62.

83. Rasmussen v. Denmark 8777/79 (28 November 1984), A87.

84. Ibid. Concurring opinion of Judge Gersing, para. 5

85. Johnston, above n. 71, para. 57. the Court from finding, in light of the clear formulation of Article 2, that capital punishment in itself raises concerns under Article 3. In Soering v. the United Kingdom, it deferred to the Contracting States that had opted for 'the normal method of amendment of the text in order to introduce a new obligation' to outlaw death penalty. ${ }^{86}$ But the case-law - in line with the reasoning in Soering - has followed up on the subsequent practice of the member states, demonstrated by the growing number of ratifications of Protocols no. 6 and 13, and now the textual reference to capital punishment in Article 2 is to be treated as inoperative. ${ }^{87}$

More recently the Court took a more doctrinal position in Maaoia v. France, where the applicant alleged that the excessive length of the proceedings initiated in order to lift an expulsion order against him violated his rights under Article 6(1). ${ }^{88}$ Article 1 of Protocol no. 7 contains specific procedural guarantees for the expulsion of aliens and in the Court's opinion, the adoption of the provision 'clearly intimated [the States'] intention not to include such procedures within the scope of Article $6 \S 1$ of the Convention'. ${ }^{89}$ It has to be noted that - unlike in the previously reviewed cases - France ratified the protocol in question; hence, the applicant was not completely deprived of the protection of the Convention.

\subsection{The Relevance of the 'Object and Purpose' in the Interpretation of the ECHR}

The core purpose of the Convention - as mentioned above - 'is to lay down certain international standards to be observed by the Contracting States in their relations with persons under their jurisdiction' and to contribute to their 'maintenance and further realisation'.90 The explicit mentions of the 'object and purpose' in the caselaw of the ECtHR can be broadly categorised into two groups. However, the teleological approach grounded in the concept serves as a basis for a number of further, allegedly ECHR-specific methods and doctrines of interpretation. While the Court does not always expressly link these interpretive techniques to the 'object and purpose', the latter arguably provides

86. Soering, above n. 53, para. 103

87. Capital punishment in peace time was abrogated in Öcalan v. Turkey [GC] 46221/99 (12 May 2005), ECHR 2005-IV 131, para. 163; while five years later the Court extended the prohibition to times of war as well in Al-Saadoon and Mufdhi v. the United Kingdom 61498/08 (2 March 2010), ECHR 2010-II 61, para. 120. Subsequent practice is discussed separately in 4.4

88. Maaouia v. France [GC] 39652/98 (5 October 2000), ECHR 2000-X 301.

89. Ibid., para. 37. The Grand Chamber in Muhammad and Muhammad v. Romania clarified the Court's position on the scope and the possible limitation of rights contained in Article 1 of Protocol no. 7. An alien's procedural rights may be restricted, but the very essence of the right cannot be impaired, and the person needs to be protected against arbitrariness. While the limitation of procedural rights in question may be duly justified, the Court takes the counterbalancing factors into consideration when ruling on the compliance with the ECHR. Muhammad and Muhammad v. Romania [GC] 80982/12 (15 October 2020).

90. See for example: Sunday Times v. the United Kingdom (no. 1) 6538/74 (26 April 1979), A30, para. 61; or Barberà, Messegué and Jabardo v. Spain 10590/83 (6 December 1988), A146, para. 78. 
- alone or in conjunction with other rules of the VCLT - a theoretical foundation for them.

The first group of cases relate to the actual application of the VCLT. In accordance with the Vienna rules, the Court has consistently emphasised that in order to ascertain the ordinary meaning of terms, the 'context' and 'the object and purpose of the provision from which they are drawn' has to be duly considered. ${ }^{91}$ As a consequence, the ECtHR has eloquently defined the 'object and purpose' of a number of Convention articles, either to support the ordinary meaning of a term or to put the applicable limitation test into framework. Without being exhaustive, the following examples are illustrative of the Court's standard practice to treat a provision's 'object and purpose' independently from that of the Convention. The ECtHR has identified several 'objects and purposes' of Article 6, depending on the issue raised in the case. For instance, the 'object and purpose' of Article 6 taken as a whole has been described such as to ensure that 'a person »charged with a criminal offence " is entitled to take part in the hearing, ${ }^{92}$ or to guarantee 'the possibility for parties to take part in the proceedings', 93 and 'the rights of the defence'. 94

The 'object and purpose' of certain provisions is rather self-evident, such as the fact that Article 5 protects individuals against arbitrary deprivation of liberty, ${ }^{95}$ or that Article 7 guarantees 'that no one should be subjected to arbitrary prosecution, conviction or punishment'. ${ }^{96}$ In spite of the explicit reference to it, judgments do not always define the 'object and purpose' of the provision under scrutiny; it is assumed that it is conspicuous and the Court only elaborates on what serves it best, ${ }^{97}$ or what runs counter to it. ${ }^{98}$

The second group of cases invoke the 'object and purpose' of the ECHR itself. The Court has consistently emphasised that 'the object and purpose of the Convention ... requires that its provisions be interpreted and applied so as to make its safeguards practical and effective'. ${ }^{99}$ The principle of effectiveness may be considered

91. For instance: Rantsev, above n. 5, para. 274; or M. and Others v. Italy and Bulgaria 40020/03 (31 July 2012), para. 147.

92. See for example: Hermi v. Italy [GC] 18114/02 (18 October 2006), ECHR 2006-XII 91, para. 59; or Dridi v. Germany 35778/11 (26 July 2018), para. 30

93. Özgür Keskin v. Turkey 12305/09 (17 October 2017), para. 32

94. Unterpertinger v. Austria 9120/80 (24 November 1986), A110, para. 31.

95. For instance: Schiesser v. Switzerland 7710/76 (4 December 1979), A34, para. 30.

96. Rohlena v. the Czech Republic [GC] 59552/08 (27 January 2015), ECHR 2015-I 185, para. 71

97. When discussing admissibility, the ECtHR has underlined numerous times that "the object and purpose of Article $35 \S 1$ of the Convention are best served by counting the six-month period as running from the date of service of the written judgment'. See for example: Dobrić v. Serbia 2611/07; 15276/07 (21 June 2011), para. 36 or Akif Hasanov v. Azerbaijan 7268/10 (19 September 2019), para. 27.

98. ' $[\mathrm{A}]$ purely negative conception [of the states' duty] would not be compatible with the object and purpose of Article 11 of the Convention'. Identoba and Others v. Georgia 73235/12 (15 December 2015), para. 94.

99. Loizidou, above n. 60, para. 73. See also: Airey v. Ireland 6289/73 (9 October 1979), A32, para. 24 as 'an overarching approach to human rights treaty interpretation', and the ECHR is no exception to this. ${ }^{100}$ According to Gardiner, the principle of effectiveness has two aspects: first, it favours an interpretation that gives effect to the terms of a treaty over one that fails to do so; second, it animates a teleological approach to interpretation. ${ }^{101}$ The case-law of the ECtHR does not draw a clear line between these two 'functions' of effectiveness. Interpretive techniques corresponding to the teleological approach, such as evolutive interpretation or the use of autonomous concepts, are dogmatically grounded in the 'object and purpose'; however, they are also linked to effectiveness in the narrower sense. As the Court has recently put it:

in order to interpret the provisions of the Convention and the Protocols thereto in the light of their object and purpose, the Court has developed additional means of interpretation through its case-law, namely the principles of autonomous interpretation and evolutive interpretation, and that of the margin of appreciation. These principles require the provisions of the Convention and the Protocols thereto to be interpreted and applied in a manner which renders their safeguards practical and effective, not theoretical and illusory. ${ }^{102}$

This suggests that the ECHR-specific methods and doctrines of interpretation advanced by the Court derive from the VCLT's imperative to interpret the text in light of the treaty's 'object and purpose'. This quote unequivocally rebuts the allegations that there are interpretive techniques in the ECHR case-law that are alien to the framework set by the VCLT.

The 'further [and effective] realisation' of human rights presupposes a forward-looking, dynamic interpretation or - in Matscher's words - 'compels an evolutive interpretation'. ${ }^{103}$ Teleological interpretation focusing on the 'object and purpose' of the ECHR is thus combined with the principle of contemporaneity embodied in the dynamic or evolutive approach, even though some authors propose to treat the two methods separately. ${ }^{104}$ This article subscribes to the definition of Gerards blending both aspects: in her understanding, the evolutive method means 'that the provisions of the Convention must be interpreted in accordance with the primary aims as defined in the Preamble, taking account of recent developments in society and science. ${ }^{105}$

100. Çali, above n. 20, at 538.

101. Gardiner, above n. 15, at 179-81 and 221-2.

102. Mihalache, above n. 47, para. 91.

103. Matscher, above n. 57, at 69.

104. Yourow - for example - argues that with the teleological method 'the Court reaches beyond Convention text to appreciate the object and purpose of the Convention as a whole', while with dynamic interpretation it interprets 'the Convention in light of current societal circumstances, secondarily incorporating the intentions of the framers of the document.' H.C. Yourow, The Margin of Appreciation in the Dynamics of European Human Rights Jurisprudence (1996), at 185.

105. J. Gerards, 'Judicial Deliberations in the European Court of Human Rights', in N. Huls, M. Adams \& J. Bomhoff (eds.), The Legitimacy of Highest Courts' Rulings. Judicial Deliberations and Beyond (2009) 407. 
The notion of 'living instrument', which requires 'that the Convention ... must be interpreted in the light of present-day conditions', ${ }^{106}$ corresponds to evolutive interpretation. They are mutually referenced as corollary arguments, or even used interchangeably. ${ }^{107}$ This technique of interpretation, although it derives from the teleological principle, also reaches beyond that and adjusts the content of terms to contemporary understandings. ${ }^{108}$ If one treats the 'object and purpose' of the Convention as the basis for dynamic interpretation, it naturally prompts the question: Did the drafters foresee and indeed intend the principle of contemporaneity to be applied to the Convention? Arato submitted that the original intention of the drafters that 'the treaty is capable of evolution' lays the ground for evolutive interpretation. ${ }^{109}$ This intention may be evidenced by how the aim of the Convention is formulated, which necessitates, or at least does not exclude, a dynamic approach. Letsas argues that the abstract intention of the drafters was to create a system capable of promoting and protecting human rights, while they also had a concrete intention about 'which situations ... human rights cover'. ${ }^{110}$ And 'the values of the ECHR, its object and purpose, fully justify ... why it should not be interpreted in terms of the drafters' concrete intentions back in 1950.' 111

The case-law undeniably suggests that the Court does recognise new aspects of rights or broaden the scope of their protection. The dynamic approach to the interpretation of the Convention is well illustrated by the gradual acceptance of the post-operative transsexuals' right of legal recognition under Article $8,{ }^{112}$ or the endorsement of the view that the denial of the right to conscientious objection constitutes an interference with and a violation of Article 9. ${ }^{113}$ There is, however, a fine line between giving provisions a contemporary understanding and judicial legislation; the latter clearly stands in tension with the principle of state consent and legal certainty.

at 429. Letsas and Fitzmaurice also consider evolutive and dynamic interpretation synonymous. See: G. Letsas, A Theory of Interpretation of the European Convention on Human Rights (2007), at 65; and M. Fitzmaurice, 'Dynamic (Evolutive) Interpretation of Treaties', 21 Hague Yearbook of International Law 101, at 102 (2008).

106. The 'living instrument' doctrine was introduced by the Court in Tyrer v. the United Kingdom 5856/72 (25 April 1978), A26, para. 31.

107. A. Mowbray, 'The Creativity of the European Court of Human Rights', 5 Human Rights Law Review 57, at 64 (2005). For a critical analysis of Tyrer see also: M.-B. Dembour, Who Believes in Human Rights? Reflections on the European Convention (2006), at 171-6.

108. For the relationship of the teleological principle and evolutive interpretation see: Fitzmaurice, above n. 105, at 117-18.

109. J. Arato, 'Subsequent Practice and Evolutive Interpretation: Techniques of Treaty Interpretation over Time and Their Diverse Consequences', 9 The Law and Practice of International Courts and Tribunals 443, at 445 (2010).

110. Letsas, above n. 105, at 70 .

111. Ibid., at 74

112. The process culminated in recognizing the right to have the new gender identity legally recognised in Christine Goodwin v. the United Kingdom [GC] 28957/95 (11 July 2002), ECHR 2002-VI 1; and has continued with eliminating the unjustifiable restrictions placed by states on the exercise of the right. E.g. Schlumpf v. Switzerland 29002/06 (8 January 2009); or A.P., Garçon and Nicot v. France 79885/12; 52471/13; 52596/13 (6 April 2017).

113. Bayatyan v. Armenia [GC] 23459/03 (7 July 2011), ECHR 2011-IV 1.
For this reason, the ECtHR has been cautious with its judicial creativity. Scholars of public international law hold that the text of the treaty ultimately limits interpretation based on the 'object and purpose'. The latter may not bring about a result that is not supported by the text; it may assist the interpreter to select which ordinary meaning shall prevail, but the outcome cannot completely disregard the text. ${ }^{114}$ The use of the dynamic interpretation has been subject to heated debates since its inception; in his dissenting opinion to Tyrer, Sir Gerard Fitzmaurice mounted a strong criticism against the majority's overreaching activism and accused the Court of pursuing a universalist agenda. ${ }^{115}$ More recently in $X$. and Others v. Austria, concerning the impossibility of second-parent adoption by same-sex partners, the partly dissenting judges emphasised that the rationale of evolutive interpretation 'is to accompany and even channel change' but not 'anticipate change, still less to try to impose it'. 116

Finally, the 'object and purpose' of the Convention is relevant in the context of autonomous concepts; in the Court's understanding - cited above - it is a means of interpretation that draws on the 'object and purpose' of the ECHR and advances effectiveness. ${ }^{117}$ However, it needs to be noted that there are further justifications based on the VCLT that may legitimise recourse to autonomous interpretation. Matscher - for instance finds support for it in Article 5 of the VCLT that prioritises the 'relevant rules of the organization' over the VCLT, ${ }^{118}$ and Killander draws attention to the relevance of Article 31(4) of the VCLT ('special meaning'). ${ }^{119}$

The ECtHR, through the use of autonomous concepts, provides a 'European meaning' to - primarily legal terms contained in the Convention. The same concept may be very differently defined in the member states and in the case-law of the Court, which creates an asymmetry in rights protection. ${ }^{120}$ In order to prevent states from circumventing their obligations by simply applying different terminology, often arbitrarily, ${ }^{121}$ and to preserve the integrity of the Convention, an equilibrium needs to be set between national discretion and European control. ${ }^{122}$ The uniform interpretation of Convention terms pre-empts the inconsistencies arising from terminological differences in the national legal systems, and for this reason it leads to the harmonisation of stand-

114. Dörr, above n. 7, at 586-7. See the ECtHR's approach in Johnston, above n. 71, para. 53 .

115. Tyrer, above n. 106, Dissenting opinion of Sir Gerard Fitzmaurice, para. 14.

116. X. and Others v. Austria [GC] 19010/07 (19 February 2013), ECHR 2013-II 1, Joint partly dissenting opinion of Judges Casadevall, Ziemele, Kovler, Jočienè, Šikuta, De Gaetano and Sicilianos, para. 23.

117. Merrills is of the same view: he links autonomous interpretation to effectiveness. Merrills, above n. 67, at 77 .

118. Matscher, above n. 57, at 71. See also: Villiger, above n. 12, at 119-20.

119. M. Killander, 'Interpreting Regional Human Rights Treaties', 7 SUR 145, at 148 (2010).

120. Letsas, above n. 105, at 42.

121. A. Legg, The Margin of Appreciation in International Human Rights Law. Deference and Proportionality (2012), at 111-12.

122. Ost, above n. 78, at 306. 
ards. ${ }^{123}$ In case of autonomous interpretation the Court disconnects the meaning of Convention terms from the domestic formulations and grants them - as Letsas puts it - 'semantic independence', ${ }^{124}$ and state actions are judged under 'the law of the Convention'. ${ }^{125}$

When defining autonomous concepts, the Court takes - in principle - the national legislation in question as 'a starting point', but the domestic law has 'only a formal and relative value and must be examined in the light of the common denominator of the respective legislation of the various Contracting States'. ${ }^{126}$ There are, however, limits to autonomous interpretation; the ECtHR cannot simply pick the most suitable standard and pay no attention to the views of domestic legislatures, and it cannot compromise the 'object and purpose' of the Convention or that of the provision at issue. ${ }^{127}$

Although autonomous interpretation appears to be a less contentious, interpretive technique in the jurisprudence of the ECtHR, its use spurred some critical remarks not only from judges but also from academics. Some argue that with its application 'the Court is striving to empower itself, to the detriment of the states'. ${ }^{128}$ Since the ECtHR assumes the role of national decision and policy-makers it may risk 'venturing into the field of legislative policy'. ${ }^{129}$ The failure to furnish evidence on how the 'common denominator' is identified and the lack of appropriate comparative analysis of the domestic laws have also made autonomous concepts subject to disapproval. ${ }^{130}$

\subsection{Subsequent Practice}

Article 31(3) adds further sources that need to be taken into account together with the 'context' when establishing the ordinary meaning of a term. Subsequent agreements and practice constitute 'forms of authentic interpretation whereby all parties themselves agree on (or at least accept) the interpretation of treaty terms by means which are extrinsic to the treaty'. ${ }^{131}$ As Villiger noted, authentic interpretation offers 'ex hypothesi' the right interpretation and consequently it is conclusive to the

123. See for example: Rainey, Wicks \& Ovey, above n. 1, at 69; and Matscher, above n. 57, at 73.

124. G. Letsas, 'The Truth in Autonomous Concepts: How to Interpret the ECHR', 15 European Journal of International Law 279, at 282 (2004).

125. Yourow, above n. 104, at 185.

126. Engel and Others v. the Netherlands 5100/71; 5101/71; 5102/71; 5354/72; 5370/72 (8 June1978), A22, para. 82.

127. See for example: Ramos Nunes de Carvalho e Sá v. Portugal [GC] 55391/13; 57728/13; 74041/13 (6 November 2018), para. 177.

128. J. Gerards, 'The European Court of Human Rights and National Courts: Giving Shape to the Nation of "Shared Responsibility"', in J. Gerards and J. Fleuren (eds.), Implementation of the European Convention on Human Rights and the Judgments of the ECtHR in National Case-Law (2014) 36, at 45.

129. König v. Germany 6232/73 (28 June 1978), A27, separate opinion of Judge Matscher, A

130. E.g. Öztürk v. Germany 8544/79 (21 February 1984), A73, dissenting opinion of Judge Matscher, A.2.; or R. Bernhardt, 'Thoughts on the Interpretation of Human-Rights Treaties', in F. Matscher and H. Petzold (eds.), Protecting Human Rights: The European Dimension. Studies in Honour of Gérard J. Wiarda (1988) 65, at 71; and Letsas, above n. 124, at 295-305.

131. Villiger, above n. 12 , at 429 ordinary meaning. ${ }^{132}$ In the ECHR case-law, subsequent agreements in Article 31(3) (a) do not play a significant role, and there is no judgment that would refer to them beyond the citation of the Vienna rules. This may be explained by the fact that such agreements would constitute an amendment to the text of the Convention, for which a separate procedure exists. Subsequent practice is, on the other hand, applied explicitly and - as it will be explained below - implicitly more frequently. In order to assess whether the case-law of the ECtHR is in harmony with the VCLT's provision on subsequent practice, a brief overview of the rule is indispensable. 'Practice' itself covers a great number of positive actions; in public international law it would simply encompass 'what states do in their relations to one another'. ${ }^{133}$ Some argue that subsequent practice must be consistent, common and concordant, ${ }^{134}$ and it has to be acquiesced to by other parties; otherwise it will remain a supplementary means of interpretation under Article 32 of the VCLT. ${ }^{135}$ However, Special Rapporteur, Georg Nolte put forward a more permissive definition: in his view, subsequent practice does not require that all parties engage in a particular practice, 'if it is "accepted" by those parties not engaged in the practice, [it could] establish a sufficient agreement regarding the interpretation of a treaty'. ${ }^{136}$ It is traditionally limited to state practice only; however, recently a wider interpretation has surfaced including - among others - the practice of UN treaty monitoring bodies as well. ${ }^{137}$ Finally, the VCLT itself is silent on the potential modifying effect of such practice, but this possibility is undoubtedly recognised in international law. ${ }^{138}$

The review of the case-law of the ECtHR presents little evidence of the widespread, explicit reliance on subsequent practice; however, it shall not lead to the quick conclusion that the notion is wholly absent from the jurisprudence. The first case when the Court considered the subsequent practice of the member states was Soering v. the United Kingdom, ${ }^{139}$ where it reviewed state practice in relation to capital punishment. It importantly noted:

[s]ubsequent practice in national penal policy, in the form of a generalised abolition of capital punishment, could be taken as establishing the agreement of the Contracting States to abrogate the exception provided for under Article $2 \S 1$ (art. 2-1) and hence to

132. Villiger, above n. 41 , at 326

133. I. Buga, Modifications of Treaties by Subsequent Practice (2018), at 23.

134. I. M. Sinclair, The Vienna Convention on the Law of Treaties (1984), at 137.

135. G. Nolte, First Report on Subsequent Agreements and Subsequent Practice in Relation to Treaty Interpretation (19 March 2013), UN doc A/CN.4/660, para. 118.

136. G. Nolte, Second Report on Subsequent Agreements and Subsequent Practice in Relation to Treaty Interpretation (26 March 2014), UN doc A/CN.4/671, para. 60.

137. Killander, above n. 119 , at 149

138. Forowicz, above n. 63 , at 37.

139. Soering, above n. 53. 
remove a textual limit on the scope for evolutive interpretation of Article 3 (art. 3). ${ }^{140}$

Since member states opted for 'the normal method of amendment of the text in order to introduce a new obligation' even the special character of the Convention could not justify modifying the interpretation through dynamic interpretation. ${ }^{141}$

This position was revisited first in Öcalan v. Turkey where the Grand Chamber endorsed the Chamber's finding on abolishing death penalty in peace time. ${ }^{142} \mathrm{By}$ the time all member states signed Protocol no. 6, three ratifications were awaited, though only Russia did not outlaw it domestically. On the basis of the strong support for Protocol no. 6, the Chamber concluded

[s]uch a marked development could now be taken as signalling the agreement of the Contracting States to abrogate, or at the very least to modify, the second sentence of Article $2 \S 1 .{ }^{143}$

The practice of the member states was consistent - in reality, even if death penalty existed in the law, executions were not carried out. Despite the fact that formally no unanimity was discernible among the member states, the practice was sufficiently concordant not to exclude the modification of the text of Article 2 on the basis of subsequent practice.

In May 2003, Protocol no. 13 completely abolishing capital punishment was opened for signature and it entered into force a year later. In 2010, the Court - on the application of two detainees who had been transferred to Iraqi custody - freshly reviewed the state practice with regard to the death penalty; when the judgment was delivered, only two member states did not sign Protocol no. 13 and three of those which signed failed to ratify it. These numbers 'together with consistent State practice in observing the moratorium on capital punishment, [were] strongly indicative that Article 2 [had] been amended so as to prohibit the death penalty in all circumstances.' ${ }^{\prime 14}$

In these cases, the subsequent practice supported evolutive interpretation and led to heightened protection. But this is not always necessarily the case. In Hassan v. the United Kingdom the Grand Chamber noted that ' $[\mathrm{t}] \mathrm{he}$ practice of the High Contracting Parties is not to derogate from their international obligations under Article 5 in order to detain persons on the basis of the Third and Fourth Geneva Conventions during international armed conflicts' ${ }^{145}$ The common practice of states supported the government's arguments that the Court should consider 'the context and the provisions of international humanitarian law when interpreting and applying Arti-

\footnotetext{
140. Ibid., para. 103

141. Ibid.

142. Öcalan, above n. 87.

143. Ibid., para. 163.

144. Al-Saadoon and Mufdhi, above n. 87 , para. 120

145. Hassan, above n. 46, para. 100.
}

cle 5 in this case'. ${ }^{146}$ Invoking Article 31(3) (b) in this case provoked wide criticism; instead of enhancing the protection under the Convention, the ECtHR practically read into Article 5 additional legitimate grounds for detention with reference to international humanitarian law. ${ }^{147}$ The dissenting judges objected to the Court's method of establishing subsequent practice calling for a more restrictive understanding; in their view, the practice has to be 'concordant, common and consistent'. ${ }^{148}$ Apart from criticising the majority for the chosen methodology, they submitted a further - probably more important - reservation: subsequent practice that meets the criteria they propose may not introduce a more restrictive interpretation of the rights at issue, in clear contradiction with the narrowly and exhaustively defined text of the Convention. ${ }^{149}$ This would also contravene the 'object and purpose' of the ECHR and fail to contribute to 'the maintenance and further realisation of Human Rights' set out in the Preamble.

In addition to the scarce explicit references to subsequent practice, the ECtHR has appealed to state practice numerous times without invoking the VCLT in the interpretive process: 'the Court confirmed that uniform, or largely uniform national legislation, and even domestic administrative practice, can in principle constitute relevant subsequent practice.' 150 This approach translates into the consensus inquiry frequently applied by the Court in various contexts. In simplistic terms, the consensus is based on a rough, methodologically questionable comparative analysis of the national (and at times international) solutions adopted by the member states and sufficient convergence - in principle - constitutes a relevant consideration for interpretation. The ECtHR still owes a definition of the European consensus, but on the basis of the case-law, commentators understand the notion rather as a 'trend' than a 'consensus' in the traditional sense of the term: 'the Court is looking to find a trend rather than an agreement as such or an outright majority'. ${ }^{151}$ Although judgments do not assess the commonalities identified in the domestic laws openly under Article 31(3) (b) of the VCLT, it may be

146. Ibid., para. 103.

147. See for example: L. Crema, 'Subsequent Practice in Hassan v. United Kingdom: When Things Seem to Go Wrong in the Life of a Living Instrument', 4 Questions of International Law 3 (2015).

148. Hassan, above n. 46, partly dissenting opinion of Judge Spano, joined by Judges Nicolaou, Bianku and Kalaydjieva, para. 13.

149. Ibid. Similarly, the lack of state practice prevented the Court to extend jurisdiction extra-territorially in Bankovic, where the Grand Chamber noted that 'State practice in the application of the Convention since its ratification to be indicative of a lack of any apprehension on the part of the Contracting States of their extra-territorial responsibility in contexts similar to the present case', i.e. state responsibility for the rights violations caused by the NATO air strikes in Belgrade. Bankovic and Others v. Belgium and Others (dec.) [GC] 52207/99 (12 December 2001), ECHR 2001-XII 333, para. 59.

150. Nolte, above n. 135, para. 54.

151. P. Mahoney and R. Kondak, 'Common Ground. A Starting Point or Destination for Comparative-Law Analysis by the European Court of Human Rights?' in M. Andenas and D. Fairgrieve (eds.), Courts and Comparative Law (2015) 119, at 122. See also: K. Dzehtsiarou, European Consensus and the Legitimacy of the European Court of Human Rights (2015), at 12. 
argued that the Court is indeed relying on subsequent practice to some extent.

The consensus is understood 'as a tool that can bring forward a particular human rights problem from the margin of appreciation and trigger evolutive interpretation', ${ }^{152}$ or in other words, it can bridge the gap between the margin of appreciation and the dynamic interpretation of the Convention. ${ }^{153}$ References to the European consensus in the case-law do not constitute a homogeneous group, but the various labels applied by the Court cover different modalities; the more conservative notions, such as European consensus, ${ }^{154}$ common European standard ${ }^{155}$ or common European approach ${ }^{156}$ have a different impact on the interpretation of the ECHR than those describing an emerging consensus or a trend, be that European ${ }^{157}$ or international. ${ }^{158}$

From the perspective of subsequent practice, only the conservative notion of consensus may be relevant; it requires a broad convergence among the member states, i.e. an almost established legal consensus. It is submitted that the trend-based consensus inquiry leading to establishing a 'hypothetical consensus' as Letsas called it, 159 is merely a supplementary means of interpretation within the meaning of the VCLT and may only be used to support interpretation based on other conventional methods and doctrines deriving from Article 31(1) of the VCLT. However, at this point it is important to differentiate between subsequent practice that results - as shown above - in the modification of the ECHR and subsequent practice that is relevant for the interpretation of the scope of the right or the assessment of the limitation clause. From the point of view of international law, in the former case, the original intent of the states supporting the evolutive treaty interpretation is not sufficient; it needs to be supported by further evidence substantiating opinio juris in the traditional sense (e.g. the signature of the relevant protocol in the cases on abolishing capital punishment). ${ }^{160}$

Recourse to the consensus inquiry has been subject to widespread criticism primarily for the lack of methodological discipline. ${ }^{161}$ Subsuming certain forms of the

152. Dzehtsiarou, above n. 151, at 24

153. Y. Arai-Takahashi, The Margin of Appreciation Doctrine and the Principle of Proportionality in the Jurisprudence of the ECHR (2002), at 199.

154. Alekseyev v. Russia 4916/07; 25924/08; 14599/09 (21 October 2010), para. 83.

155. Shtukaturov v. Russia 44009/05 (27 March 2008), para. 95.

156. Sheffield and Horsham v. the United Kingdom [GC] 22985/93; 233390/94 (30 June 1998), para. 57.

157. Vallianatos and Others v. Greece [GC] 29381/09; 32684/09 (07 October 2013), ECHR 2013-VI 131, para. 91.

158. Christine Goodwin, above n. 112, para. 85. On the two notions of the consensus see also: E. Polgari, 'European Consensus: A Conservative and a Dynamic Force in European Human Rights', 12 Vienna Journal of International Constitutional Law 1 (2018).

159. Letsas, above n. 40, at 531.

160. A similar view is advanced in A. Seibert-Fohr, 'The Effect of Subsequent Practice on the European Convention on Human Rights. Considerations from a General International Law Perspective', in A. van Aaken and I. Motoc, The European Convention on Human Rights and General International Law (2017) 61, at 80.

161. See for example: J.L. Murray, 'Consensus: Concordance, or Hegemony of the Majority?' in Dialogue between Judges (2008) 37, at 39; or consensus inquiry under subsequent practice and distinguishing their normative value on objective grounds, i.e. how consistent and common the state practice is, would add democratic legitimacy to its use; ultimately the solution elevated to the level of the Convention would verifiably originate from the member states. This approach is not new to the Court. In Bayatyan v. Armenia, the Grand Chamber overruled the Convention organs' prior case-law on conscientious objection to military service - among others - on the basis that 'there was nearly a consensus among all Council of Europe member States'. ${ }^{162}$ At the time the right was recognised, only two countries did not share the 'virtually general consensus' on the issue, and thus the practice of the member states and other international developments warranted a dynamic approach. ${ }^{163}$ If one accepts - as Nolte submitted - that member states are aware of their obligations under the ECHR when they legislate on a certain issue and their actions follow from a 'bona fide understanding of [their] obligations', ${ }^{164}$ embracing a standard deriving from national laws - pending that it is widely shared - with reference to subsequent practice leading to an evolutive interpretation is not at odds with state consent. ${ }^{165}$

\subsection{Systemic Integration}

Article 31(3) (c) embodies the principle of systemic integration and mandates the consideration of 'any relevant rules of international law in the relations between the parties' together with 'context'. ${ }^{166}$ In addition to the general rule in Article 31(1), this is the VCLT provision that has been cited the most frequently by the ECtHR and analysed by scholarly literature extensively. ${ }^{167}$ Without attempting to give a thorough overview, the following section aims to briefly shed light on the ECtHR's understanding of this rule.

The principle of systemic integration is the answer of international lawyers to the problem of fragmentation; it

K. Dzehtsiarou, 'Comparative Law in the Reasoning of the European Court of Human Rights', 10 University College Dublin Law Review 109 , at 118-26 (2010).

162. Bayatyan, above n. 113, para. 103

163. Ibid., paras. 108-9.

164. Nolte, above n. 136, para. 14.

165. Recently European consensus has also been conceptualised as the manifestation of a 'regional custom'. See: S. Besson, 'Comparative Law and Human Rights', in M. Reimann and R. Zimmermann (eds.), The Oxford Handbook of Comparative Law (2019) 1222, at 1231; or I. Ziemele, 'European Consensus and International Law', in A. van Aaken and I. Motoc, The European Convention on Human Rights and General International Law (2017) 23, at 32-6.

166. McLachlan, above n. 21, at 280. Not everyone equates the two: see A. Rachovitsa, 'The Principle of Systemic Integration in Human Rights Law', 66 International and Comparative Law Quarterly 557, at 560 (2017)

167. See for example: Forowicz, above n. 63; V.P. Tzevelekos, 'The Use of Article 31(3)(C) of the VCLT in the Case Law of the ECtHR: An Effective Anti-Fragmentation Tool or a Selective Loophole for the Reinforcement of Human Rights Teleology - Between Evolution and Systemic Integration', 31 Michigan Journal of International Law 621 (2010); or A. Rachovitsa, 'Fragmentation of International Law Revisited: Insights, Good Practices, and Lessons to be Learned from the Case Law of the European Court of Human Rights', 28 Leiden Journal of International Law 863 (2015). 
'goes further than merely restate the applicability of general international law in the operation of particular treaties. It points to a need to take into account the normative environment more widely.' ${ }^{, 168}$ Article 31(1) (c) endorses the need for a contemporary interpretation of treaties. The provision clearly refers to rules of international law as defined in Article 38 of the ICJ Statute, and the term 'applicable' includes - in principle - binding norms only. ${ }^{169}$ Relevance is broadly understood, and Gardiner suggests that rules 'touching on the same subject matter as the treaty provision ... being interpreted or which in any way affect that interpretation' are to be taken into consideration. ${ }^{170}$ While the term 'parties' may give rise to issues in general international law, in the context of the ECHR it may be conclusively established that it refers to the member states.

The review of the case-law suggests that the ECtHR does not apply the strict standards laid down with regard to Article 31(3) (c) of the VCLT. It has repeatedly confirmed that the Convention 'cannot be interpreted in a vacuum' and it 'must also take the relevant rules of international law into account'. ${ }^{171}$ However, the pool of sources is not limited to 'applicable rules'; the ECtHR is open to any international law instrument - including soft law - when performing interpretation with reference to VCLT. It has thus considered, among others, reports from specialised bodies, ${ }^{172}$ the jurisprudence of other human rights organs ${ }^{173}$ or a wide range of soft law documents. ${ }^{174}$

Admittedly, the Court reserves the right to determine which sources it reckons as relevant and accordingly how much weight it attributes to them. ${ }^{175}$ Leaving room for cherry-picking weakens the normative value of systemic integration and the Court itself seems to be mindful of its limits. The case-law suggests that indeed a difference needs to be made between establishing 'a continuous evolution in the norms and principles applied in international law'176 or ' $[\mathrm{t}]$ he consensus emerging from specialised international instruments and from the practice of Contracting States', 177 on the one hand, and confirming that the measure at issue reflects 'generally recognised rules of public international law', on the other

168. ILC, 'Fragmentation of International Law: Difficulties Arising from the Diversification and Expansion of International Law' (13 April 2006), UN Doc A/CN.4/L.682, para. 415.

169. Villiger, above n. 12 , at $432-3$

170. Gardiner, above n. 15, at 299.

171. See for example: Fogarty v. the United Kingdom [GC] 37112/97 (21 November 2001), ECHR 2001-XI 157, para. 35.

172. Kiyutin v. Russia 2700/10 (10 March 2011), ECHR 2011-II 29, para. 67 with references to the World Health Organization.

173. See for example Bayatyan, above n. 113, with references to the Human Rights Committee's case-law (paras. 59-60 and 105); or Mamatkulov and Askarov v. Turkey [GC] 46827/99; $46951 / 99$ (4 February 2005), ECtHR 2005-I 293 for an outlook to the Inter-American Court of Human Rights (paras. 51-3 and 112).

174. E.g. Oliari and Others v. Italy 18766/11; 36030/11 (21 July 2015), paras. 56-61 and 166 where the ECtHR took into account soft law from other Council of Europe bodies.

175. Tănase v. Moldova [GC] 7/08 (27 April 2010), ECHR 2010-III 361, para. 176.

176. Magyar Helsinki Bizottság, above n. 47, para. 123.

177. Demir and Baykara, above n. 48, para. 85. hand. ${ }^{178}$ While in the first group of cases the consensus inquiry is conflated with systemic integration in support of evolutive interpretation, and thus these may only be - as explained above - ancillary or supportive arguments, in the latter cases, the Court examines whether there is applicable customary law norm. The latter, to date, has been limited to state immunity in the context of Article 6(1).

The ECtHR - while retaining some flexibility in interpreting Article 31(3) (c) of the VCLT - has expressed commitment to an integrationist approach. It usually does not require that the developments in international law constitute a regional custom in the strict sense, and linking systemic integration to the consensus inquiry and evolutive interpretation allows it to disregard the lack of unanimity.

\section{Conclusion}

In the Golder v. the United Kingdom ${ }^{179}$ case, the ECtHR unconditionally endorsed Articles 31-33 of the VCLT even before they entered into force, recognising that the rules on interpretation are reflections of customary international law norms. In spite of the scarce explicit mentions, all the constitutive elements of the Vienna rules can be traced in the jurisprudence. This article argued that the Court has not developed a competing framework for the interpretation of the Convention; on the contrary, the main methods and doctrines correspond to the interpretive techniques prescribed in the VCLT. While the ECtHR is the final authority to interpret the Convention, it has not abused its prerogative, and its methods and doctrines of interpretation can be accommodated within the Vienna rules. We must, however, not lose sight of the 'special character' and the 'object and purpose' of the Convention; these mandate an interpretation that ensures the effectiveness of the safeguards embodied in the founding document. Effectiveness also animates a teleological approach to the text, and the 'object and purpose' of the ECHR serves - in the Court's view - as a justification or source not only for the evolutive interpretation, but also for autonomous concepts and the margin of appreciation.

Over the years, the ECtHR has been subject to widespread criticism for its activism, for its lack of respect for state consent and state sovereignty and for encroaching on territories that have been reserved for the member states. ${ }^{180}$ The growing importance of the principle of subsidiarity and the related doctrine of margin of appreciation questions the Court's ability to develop the guarantees further as required by the 'object and purpose' of the Convention. The most contested methods of interpretation are naturally those that result in the expansion of the protection under the ECHR and, for this reason, grounding them in the framework of the

178. For example: Cudak v. Lithuania [GC] 15869/02 (23 March 2010), ECHR 2010-III 153, para. 57.

179. Golder, above n. 42.

180. P. Popelier, S. Lambrecht \& K. Lemmens (eds.), Criticism of the European Court of Human Rights - Shifting the Convention System: CounterDynamics at the National and EU Level (2016). 
VCLT may add further legitimacy to the jurisprudence of the Court and protect it from charges of overreaching activism. In order to demonstrate the disciplining potential of the Vienna rules, the article proposed to reconceptualise the consensus inquiry - an often-contested interpretive technique - in light of Article 31(3) (b) of the VCLT and differentiate between trends and emerging consensus on one hand, and European consensus or the conservative notion of consensus, on the other. While the former type of convergence among the member states constitutes only a 'hypothetical consensus' that may serve as supplementary means of interpretation, European consensus may be understood as subsequent practice within the meaning of the Vienna rules. Subsuming the consensus inquiry under subsequent practice would inject methodological rigour to its use, and developments based on a broad(er) agreement among the member states would encounter less fierce criticism. 